\title{
IMPLEMENTING POWTOON TO IMPROVE STUDENTS' INTERNATIONAL CULTURE UNDERSTANDING IN ENGLISH CLASS
}

\author{
Lulud Oktaviani ${ }^{1}$, Berlinda Mandasari ${ }^{2}$, Reynita Adlina Maharani ${ }^{3}$ \\ Universitas Teknokrat Indonesia, ${ }^{1,2,3}$
}

lulud_oktaviani@teknokrat.ac.id ${ }^{1}$, berlinda@teknokra.ac.id², reynitaadlinamaharani@gmail.com³

\begin{abstract}
\begin{tabular}{ll}
\hline Received: 6 May 2020 & Accepted: 11 June 2020 \\
\hline
\end{tabular}
Abstract

The use of technology has increased rapidly in our daily activities since first industrial revolution and its features also becomes more and more enchanting from time to time. Thus, people are used to work with it to lighten their jobs, including education, such as delivering/learning material through multimedia, online teaching and learning, etc. It is line with the result of preliminary study that $56 \%$ students of English Literature at Universitas Teknokrat Indonesia (UTI) said their lecturers used more technology in class. Thus, the researchers used classroom action research in order to know whether the use of technology does not only help the lecturer in delivering material in a class but also improve students' international culture understanding in English class. To collect the data, the researchers used observations, tests, and questionnaires. The subjects of this research were second semester students of English Literature at UTI. The finding showed that students' international culture understanding improved after each cycle. Improvement was also seen based on the result of observations that students showed positive behaviour during the teaching and learning activity.
\end{abstract}

Published : 31 July 2020

Keywords: English class, International culture, web-based medium

\section{To cite this article:}

Oktaviani, L., Mandasari, B., \& Maharani, R. A. (2020). Implementing Powtoon to Improve Students' International Culture Understanding in English Class. Journal of Research on Language Education, 1(1), 19-25.

\section{INTRODUCTION}

Technology is a part of human life. It contributes to the development of the society and helps human lives day to day basis. However, technology did not instantly begin as advanced as it is nowadays. It has history of its own growth or development throughout the centuries. Starting from steam engine until artificial intelligence, the use of technology and it features has increased from time to time. Technology really helps human daily activities, such as transportation, company production, limitless-place communication, and even in learning knowledge-education. The growth and features of technology itself can be seen from the four-stage of revolution industry as follows:

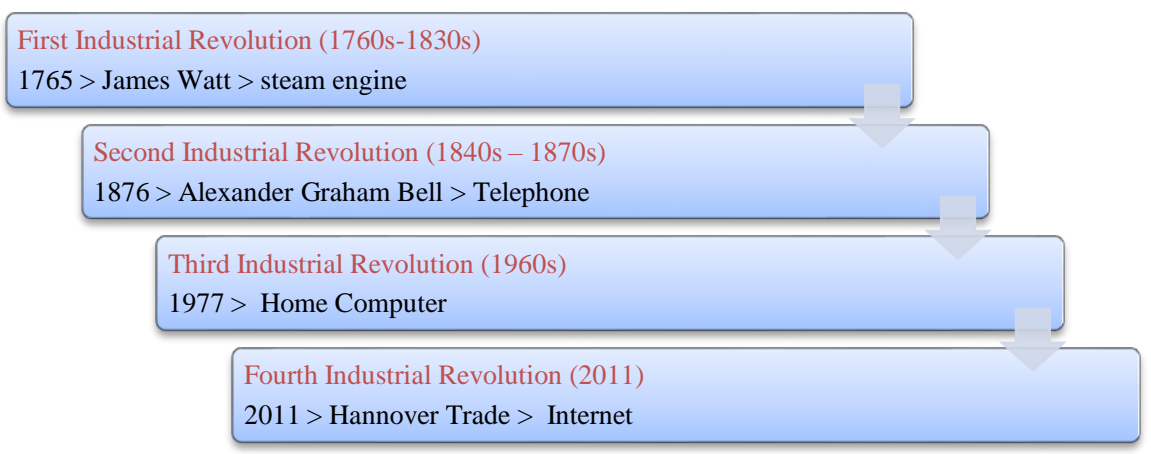

Figure 1. Phases of Industrial Revolution (Sharman, 2018) 
The diagram above showed that features of technology has growth from time to time, it starts with the invention of practical of steam engine by James Watt in the first industrial revolution that began from 1760s until 1830 s and as a result of the steam engine invention, human lives were helped by its existence. In the second industrial revolution that span from 1840s until 1870s, a telephone was invented by Alexander Graham Bell in 1876 that helped humans to communicate with each other with a distance that separated them. It created a limitless place and boundary. Next, in the third industrial revolution that began in 1960s and also known as the digital revolution, technology of the world increased in digital sense. A home computer was available in the 1977 and the users of the computer were able to do some works and even play some games. Then, the fourth industrial revolution which is the era we live in. The fourth industrial revolution was firstly mentioned by Bosch at Hannover Trade in 2011 and technology was developed rapidly and it is still developing in this era. Year by year, humans find new technology that able to ease the burden of their daily activities and online schools are also available in this era which means the education is conducted with the help of internet connection.

Internet connection and technology are two things that cannot be separated nowadays, especially in education system. Many lecturers and researchers try to apply them in their teaching and learning process because their benefits. Dogruer et.al (2011) conducted a research about the use of internet in education purposes and it showed that $80 \%$ of participants like to use internet more in learning because its efficiency and easiness to find and share information. Moreover, Dabas (2018) found that technology usage in education system can give several benefits, such as improving the quality of teaching and learning, creating effective teaching and learning process, and many more. Sari and Wahyudin (2019) also said that using technology in learning can influence students' motivation, attitude, and engagement. Thus, applying internet and technology may also be beneficial for education, especially teaching and learning process in Indonesia.

Universitas Teknokrat Indonesia (UTI) is one of campuses in Lampung which encourages the lecturers to use technology and internet in teaching and learning process. This campus also provides internet connection and computer in every classes to support this policy. Moreover, in a second semester, the English Literature students need to learn about international culture. It would be very difficult to study this material without pictures or any kind visualization for the students to see because everyone has their own way of imagining things. Fortunately, the era has developed into such a modern era in the fourth industrial revolution with its advanced technology and there are applications that are very helpful to help students' education, Powtoon. It helps students to study a material beyond a class.

Powtoon is an application that enables students to explore their creativity in making animated presentations. Moreover, when the animated presentations are shown to the other students they will be able to engage the students' attention at once because of the uniqueness of the presentations and the students will also be able to improve their knowledge related to the material at the same time by listening to the friends' explanation and also the images they see on the animated presentations. Thus, the researchers conducted this research to find out that Powtoon was able to help the improvement of students' understanding in international culture for English Literature students since the researchers have conducted a research in using powtoon in reading class and has successfully done (Oktaviani and Mandasari, 2019). Ayu (2020) also said that technology in higher education especially e-learning can enhance students' learning experiences.

\section{RESEARCH METHOD}

To collect the data, the researchers used observations, tests, and questionnaires. The subjects of this research were second semester students of English Literature at UTI. The finding showed that students' international culture understanding improved after each cycle. In this research we used Classroom Action Research (CAR) method. CAR is a method of finding out what works best in your own classroom so that you can improve student learning (Mettetal, 2001). The goals of this method are to improve teacher's teaching in his/her classroom, department, or school and also to improve students' understanding. There are some ways that should be done before attaining the result of the research. They are: 


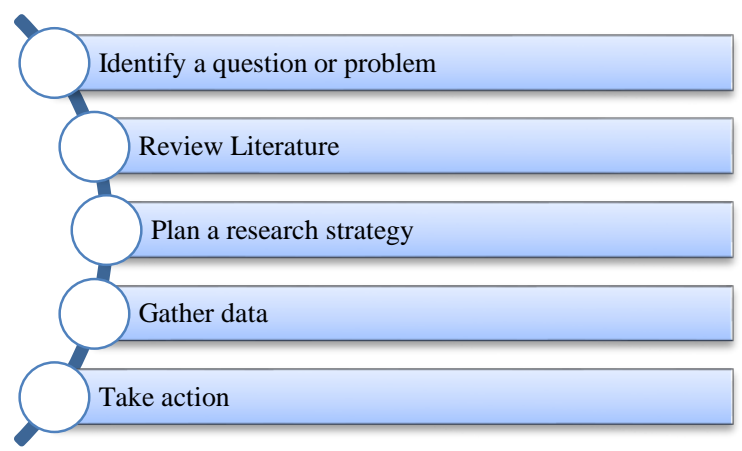

Figure 2. Stages to conduct CAR

\section{- Identify a question or problem}

In identifying a problem, the researchers gave a questionnaire to students and found that technology really impacted students' ways of learning as it seemed in the table below.

Table 1. Result of Preliminary Study

\begin{tabular}{|c|c|c|c|c|c|}
\hline No. & Statements & $\begin{array}{l}\text { Sangat } \\
\text { Tidak } \\
\text { Setuju } \\
(\%)\end{array}$ & $\begin{array}{l}\text { Tidak } \\
\text { Setuju } \\
(\%)\end{array}$ & $\begin{array}{l}\text { Setuju } \\
(\%)\end{array}$ & $\begin{array}{l}\text { Sangat } \\
\text { Setuju } \\
(\%)\end{array}$ \\
\hline 1. & My lecturers always use teaching media in a class. & 8 & 8 & 36 & 48 \\
\hline 2. & My lecturers always use white board in teaching. & 4 & 24 & 56 & 16 \\
\hline 3. & $\begin{array}{l}\text { My lecturers often use visual media non computer in teaching, such as picture, } \\
\text { poster, printed diagram, etc. }\end{array}$ & 12 & 24 & 48 & 16 \\
\hline 4. & My lecturers often use audio media in teaching. & 12.5 & 12.5 & 41.7 & 33.3 \\
\hline 5. & My lecturers always use power point in class. & 8 & 8 & 44 & 40 \\
\hline 6. & $\begin{array}{l}\text { My lecturers always use many kinds of media in one semester, so students do } \\
\text { not get bored. }\end{array}$ & 12 & 16 & 16 & 56 \\
\hline 7. & My lecturers often notice the same media and material to teach parallel classes. & 4 & 24 & 48 & 24 \\
\hline 8. & I want my lecturers to use different teaching media for the same subject. & 12 & 24 & 16 & 48 \\
\hline
\end{tabular}

Table 1 showed that the use of media and technology were high and above $50 \%$. Besides, the students also expected that their lecturers used different teaching media for teaching a subject in one semester. Thus, the researchers wanted to identify that technology could improve students' understanding toward a material given, especially tourism.

\section{- Review Literature}

After decided the problem to be investigated, the researchers also found that technology can improve students' academic performance. It is in line with Sheldon (2007) that technology can improve academic performance in Elementary classroom. So, the researchers were highly intrigued what the result would be for university students.

\section{- Plan a research strategy}

The researchers planned all the research strategies, how to get our hands on the result of the research, and made a conclusion that would do the research through Pre-test and Post-test to see the improvement of the students' understanding in International Culture.

\section{- Gather data}

The data were gathered from English Literature of B class in second semester at Universitas Teknokrat Indonesia. The researchers encouraged the students to use

\section{- Take action}

In the last, the researchers executed the best decision in order to apply technology in English class based on the data that had been gathered.

After finishing all of those steps that are written above, the researchers get the result which also lead us to determine the best decision regarding applying technology (Powtoon) in English class in Universitas Teknokrat Indonesia. 
Journal of Research on Language Education (JoRLE), Vol: 1, No: 1, 19-25

\section{FINDINGS AND DISCUSSION}

The researchers applied Powtoon usage in English Literature of B Class for four cycles. The data of Pretest and Post-test were provided in the table below:

Table 2. Data of Pre-Test and Post-Test

\begin{tabular}{|c|c|c|c|c|c|c|c|c|c|}
\hline \multirow[t]{2}{*}{ No } & \multirow[t]{2}{*}{ Name } & \multicolumn{2}{|c|}{$\begin{array}{l}\text { Cycle } 1 \text { (International } \\
\text { Event) }\end{array}$} & \multicolumn{2}{|c|}{ Cycle 2 (Cuisine) } & \multicolumn{2}{|c|}{$\begin{array}{c}\text { Cycle } 3 \text { (Tourism } \\
\text { Place) }\end{array}$} & \multicolumn{2}{|c|}{ Cycle 4 (Traveling) } \\
\hline & & Pre-test & Post-test & Pre-test & Post-test & Pre-test & Post-test & Pre-test & Post-test \\
\hline 1 & Subject 1 & 40 & 80 & 45 & 80 & 80 & 100 & 0 & 0 \\
\hline 2 & Subject 2 & 0 & 100 & 40 & 80 & 20 & 100 & 0 & 0 \\
\hline 3. & Subject 3 & 40 & 80 & 50 & 100 & 50 & 100 & 75 & 100 \\
\hline 4. & Subject 4 & 40 & 80 & 30 & 30 & 60 & 100 & 65 & 65 \\
\hline 5 & Subject 5 & 80 & 100 & 35 & 100 & 60 & 100 & 60 & 100 \\
\hline 6 & Subject 6 & 40 & 60 & 40 & 80 & 70 & 80 & 75 & 100 \\
\hline 7. & Subject 7 & 80 & 100 & 45 & 100 & 60 & 100 & 60 & 80 \\
\hline 8 & Subject 8 & 0 & 80 & 30 & 100 & 80 & 100 & 60 & 100 \\
\hline 9 & Subject 9 & 70 & 100 & 50 & 100 & 50 & 100 & 75 & 100 \\
\hline 10 & Subject 10 & 40 & 80 & 25 & 80 & 60 & 100 & 75 & 100 \\
\hline 11 & Subject 11 & 0 & 80 & 50 & 80 & 40 & 100 & 75 & 100 \\
\hline 12 & Subject 12 & 20 & 100 & 40 & 80 & 50 & 100 & 65 & 100 \\
\hline 13 & Subject 13 & 0 & 100 & 65 & 80 & 30 & 80 & 45 & 100 \\
\hline 14 & Subject 14 & 0 & 0 & 50 & 100 & 80 & 100 & 65 & 100 \\
\hline 15 & Subject 15 & 100 & 100 & 85 & 100 & 100 & 100 & 0 & 0 \\
\hline 16 & Subject 16 & 90 & 100 & 85 & 100 & 0 & 100 & 80 & 100 \\
\hline 17 & Subject 17 & 70 & 85 & 85 & 100 & 90 & 90 & 80 & 100 \\
\hline 18 & Subject 18 & 80 & 100 & 85 & 100 & 0 & 0 & 78 & 100 \\
\hline 19 & Subject 19 & 0 & 0 & 70 & 80 & 40 & 100 & 70 & 100 \\
\hline 20 & Subject 20 & 20 & 100 & 65 & 100 & 50 & 100 & 65 & 100 \\
\hline 21 & Subject 21 & 20 & 100 & 60 & 80 & 50 & 100 & 80 & 100 \\
\hline 22 & Subject 22 & 0 & 0 & 80 & 100 & 60 & 100 & 95 & 100 \\
\hline 23 & Subject 23 & 40 & 100 & 60 & 80 & 50 & 100 & 60 & 100 \\
\hline 24 & Subject 24 & 20 & 100 & 70 & 80 & 30 & 100 & 80 & 100 \\
\hline 25 & Subject 25 & 70 & 100 & 65 & 100 & 80 & 100 & 80 & 100 \\
\hline 26 & Subject 26 & 35 & 100 & 60 & 100 & 75 & 100 & 80 & 100 \\
\hline 27 & Subject 27 & 0 & 0 & 20 & 80 & 20 & 100 & 80 & 100 \\
\hline 28 & Subject 28 & 20 & 40 & 60 & 100 & 80 & 80 & 0 & 0 \\
\hline 29 & Subject 29 & 0 & 60 & 40 & 80 & 0 & 0 & 60 & 100 \\
\hline 30 & Subject 30 & 0 & 0 & 60 & 40 & 60 & 100 & 0 & 65 \\
\hline 31 & Subject 31 & 20 & 100 & 80 & 90 & 50 & 90 & 70 & 100 \\
\hline 32 & Subject 32 & 0 & 0 & 80 & 100 & 0 & 0 & 60 & 100 \\
\hline 33 & Subject 33 & 20 & 100 & 80 & 100 & 80 & 100 & 60 & 100 \\
\hline 34 & Subject 34 & 80 & 100 & 80 & 80 & 100 & 100 & 80 & 80 \\
\hline 35 & Subject 35 & 0 & 100 & 30 & 100 & 80 & 80 & 60 & 100 \\
\hline 36 & Subject 36 & 0 & 0 & 80 & 100 & 0 & 0 & 80 & 100 \\
\hline 37 & Subject 37 & 80 & 80 & 60 & 60 & 60 & 80 & 60 & 80 \\
\hline 38 & Subject 38 & 85 & 100 & 35 & 65 & 0 & 0 & 75 & 100 \\
\hline 39 & Subject 39 & 0 & 0 & 65 & 100 & 20 & 100 & 55 & 100 \\
\hline 40 & Subject 40 & 90 & 90 & 60 & 100 & 0 & 100 & 0 & 100 \\
\hline 41 & Subject 41 & 0 & 0 & 0 & 0 & 60 & 100 & 60 & 100 \\
\hline 42 & Subject 42 & 0 & 0 & 0 & 0 & 0 & 0 & 65 & 100 \\
\hline 43 & Subject 43 & 0 & 100 & 0 & 0 & 80 & 80 & 85 & 100 \\
\hline 44 & Subject 44 & 0 & 0 & 0 & 0 & 0 & 0 & 60 & 100 \\
\hline 45 & Subject 45 & 20 & 100 & 0 & 0 & 50 & 100 & 65 & 100 \\
\hline
\end{tabular}


Based on Table 2, there were 45 students in English Literature of B class who joined four cycles with four different materials. After four cycles, the scores of post-tests became higher as it was shown in the Figure 2 below.

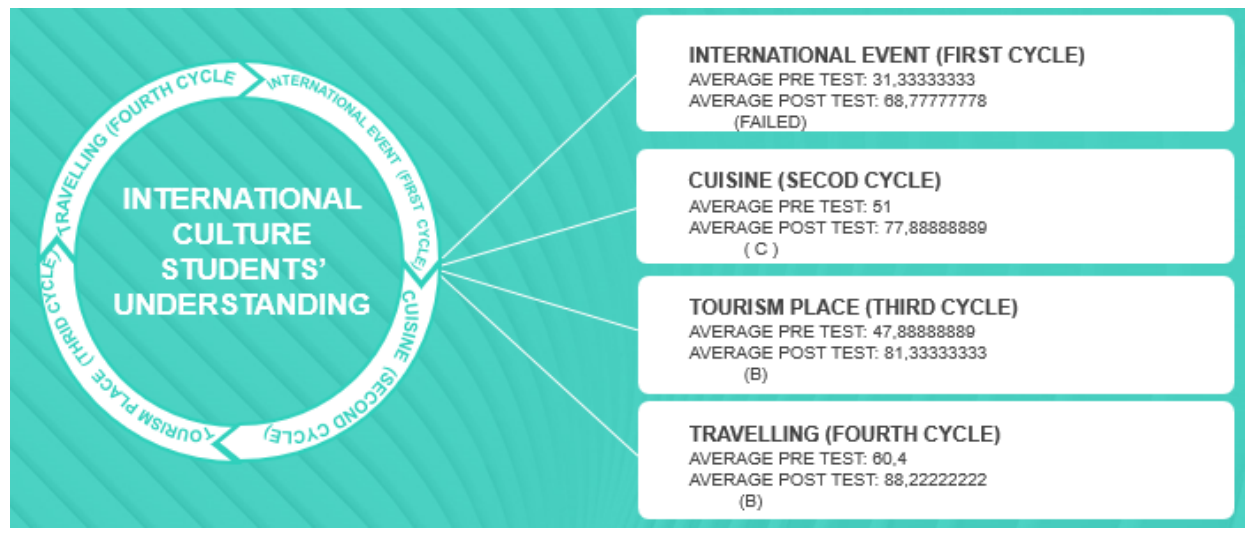

Figure 2. Result of Pre-Test and Post-Test

Figure 2 showed that in the first cycle, average score of post-tests was 68,78 which belonged to D. In the second cycle, the students' average post-tests score became higher which was 77,89. Fortunately, in the third and fourth cycles, the students' average post-tests score reached 81,33 and 88,22 which belonged to B. The reason of conducting this research until four cycles was because tourism material is given in Basic Reading class or skill class. In skill class, the students can only pass the class if their score are either A or B. Thus, after the third cycle, the researchers wanted to conduct on more cycle to make sure that technology can really make students improve their understanding in learning.

Beside using test, the researchers also used a questionnaire to see students' opinion toward Powtoon usage as it was shown in the Table 3 below:

Table 3. Students' Opinion toward Powtoon Usage

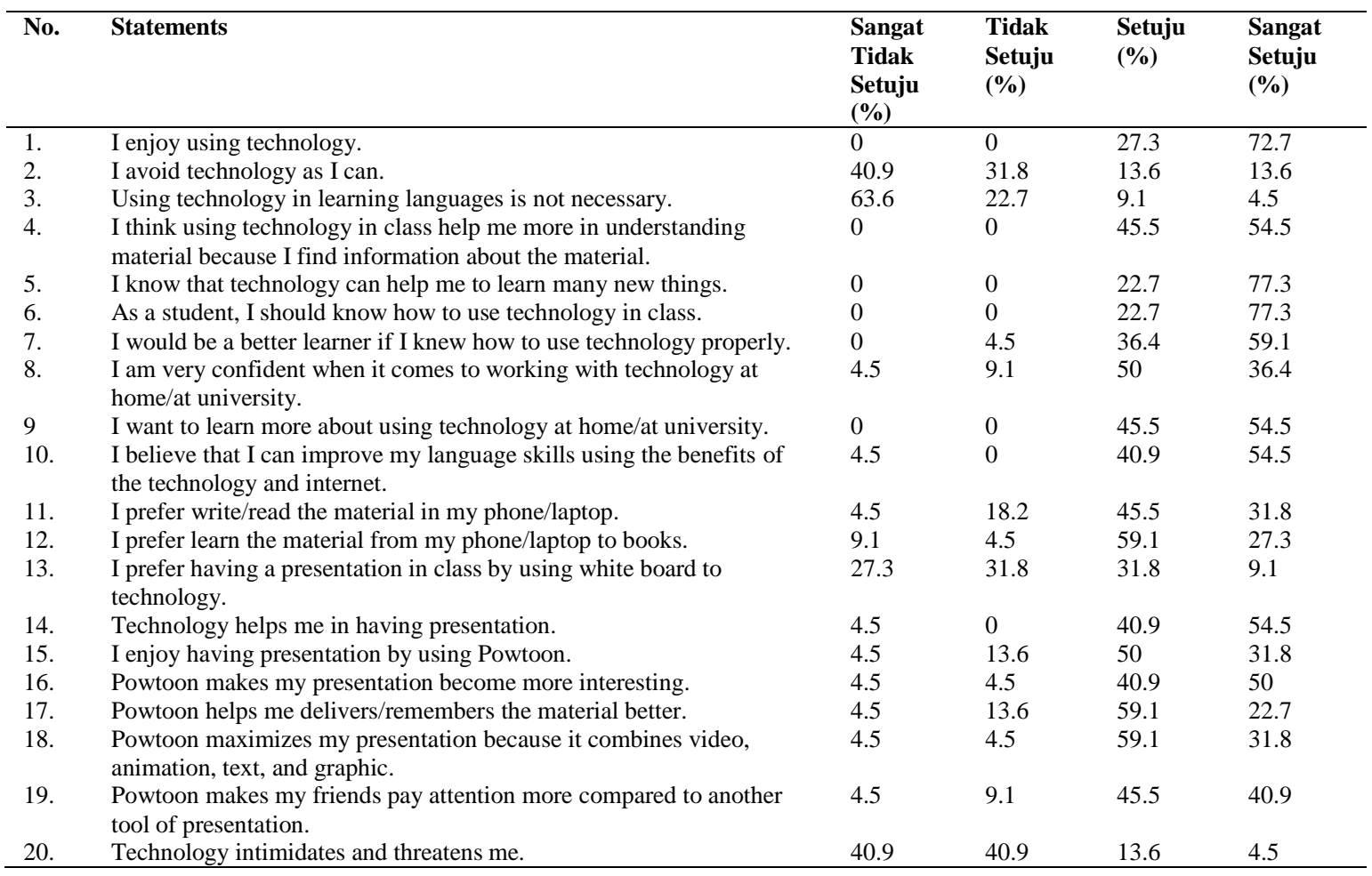

The result showed that students enjoyed using technology for learning and they thought it was really helpful (statement 1-5). It is in line with Oktaviani and Desiarti (2017) that sudents who are even in university freshmen really enjoyed using technology in teaching and learning process since it visualized their abstract 
thinking. Next, more than $50 \%$ students were confident in using it, wanted to learn it more, and felt it can improve their understanding (statement 6-10) because they are mostly digital natives who have high enthuastism in using teachnology (). More than a half student also liked using technology in learning in their learning activities (statement 11-14) because they can learn anytime and anywhere without having a limitation time and places (Aminatun and Oktaviani, 2019). Toward the Powtoon usage, more than $80 \%$ students taught that it helps them delivering/remembering/maximizing their presentation, made the presentation became more interesting, and could attract their friends' attention (statement 15-19). Furthermore, as Oktaviani and Mandasari (2020) said technology in teaching and learning has at least two functions, they are improving students' ability in learning and students' ability in using technology it self since nowadays the students need to know or use more technology in teaching and learning process.

\section{CONCLUSION}

It is obvious that using Powtoon in learning English can improve students' understanding. As technology and internet are part of students' life, they are can be applied and accepted by the students easily. Its features were really attracted students' attention to learn. So, this application may also be used to teach another material for university students or even in different level of students.

\section{REFERENCES}

Aminatun, D. \& Oktaviani, L. (2019). Memrise: Promoting Students' Autonomous Learning Skills through Language Learning Application. Metathesis: Journal of English Language, Literature, and Teaching. 3(2), $214-224$. DOI: $10.31002 /$ metathesis.v3i2.1982.

Ayu, M. (2020). Online learning: Leading e-learning at higher education. The Journal of English Literacy and Education, $7(1), 47-54$.

Dabbas, N. 2018. Role of Computer and Information Technology in Education System. International Journal of Engineering and Techniques, 4(1), 570-574.

Dogruer, N., Eyyam R., \& Menevis, I. 2011. The use of the internet for educational purposes. Procedia - Social and Behavioral Sciences, 28, $606-611$.

Mettetal, G. 2001. The What, Why and How of Classroom Action Research. The Journal of Scholarship of Teaching and Learning (JoSoTL), 2(1), 6-13.

Oktaviani, L. \& Desiarti, E. (2017). A Lecturer's and Students' Perspective toward Ethnic Snake Game in Speaking Class at Universitas Muhammadiyah Malang. TEKNOSASTIK: Journal Bahasa dan Sastra. 15(2), 53-59. DOI: https://doi.org/10.33365/ts.v15i2.98

Oktaviani, L. \& Mandasari, B. (2019). Powtoon: Presenting SQ3R Implementation in Reading Class through A Web-Based Medium. Proceedings Humanies Universitas Pamulang 581-589. Retrieved on http://openjournal.unpam.ac.id/index.php/Proceedings/article/view/4714/3519 at May $22^{\text {nd }} 2020$.

Oktaviani, L. \& Mandasari, B. (2020). Powtoon: A Digital Medium to Optimize Students' Cultural Presentation in ELT Classroom. Teknosastik: Jurnal Bahasa dan Sastra, 18(1), 33-41. DOI: https://doi.org/10.33365/ts.v18i1.526.

Sari, F.M. and Wahyudin. A.Y. (2019). Undergraduate Students' Perceptions Toward Blended Learning through Instagram in English for Business Class. International Journal of Language Education 3(1), 64-73. Retrieved at https://eric.ed.gov/?id=EJ1244402

Sharman, J. 2018. Four phases of industrial revolution. Retrieved from https://www.thenbs.com/knowledge/four-phases-ofindustrial-revolution-phase-one.

Sheldon, A. L. 2007. Technology as a Tool for Improving Academic Performance and Morale in the Elementary Classroom. Mathematical and Computing Sciences Masters. Paper 65.

Zur, O. \& Zur, A. (2011). On Digital Immigrants and Digital Natives: How the Digital Divide Affects Families Educational Institutions, and the Workplace. Zur Institute - Online Publication. Retrieved on month/day/yearfrom http://www.zurinstitute.com/digital_divide.html.

\section{BIOGRAPHIES OF AUTHORS}

Lulud Oktaviani is an English Education Lecturer in Universitas Teknokrat Indonesia (UTI). Besides teaching, she is also active in joining as a presenter at national and international conferences and publishing her research in proceedings and journals. Her research interest is teaching media, English teaching, and learning, English as a second language. Moreover, she also has obtained funding from the Directorate of Research and Community Service in Higher Education five times for Penelitian Dosen Pemula (PDP) and Program Kemitraan Masyarakat (PKM).

Berlinda Mandasari is an English education lecturer at Universitas Teknokrat Indonesia. Her research interest focuses on teaching English as Foreign Language, language assessment and teaching media. She has ever been awarded research Grants in 2018 and 2019 form Ministry of Research. Technology and Higher Education for the program of Penelitian Dosen 
Pemula (PDP). Now, she is working for the research on Blended Learning as well as accomplishing a handbook of Preintermediate grammar to publish.

Reynita Adlina Maharani is an English Literature student in her final year at Universitas Teknokrat Indonesia. She has the experiences of being co-writer of plays at the university. She also has published three literary works on an online platform, Wattpad. In the meantime, she is currently working on her undergraduate thesis in the field of literature. 